topterygia) de gran tamaño, del Terciario temprano Antártida. Ameghiniana, 17:273-276.

- AND A. L. CiONE. 1978. Una nueva colección de vertebrados del Terciaria inferior de la Isla Vicecomodoro Marambio (Seymour Island) Antártida. Obra Centenario Museo de La Plata, 5:73-79.

- AND C. P. TAMBUSSI. 1985. Nuevos restos de Odontopterygia (Aves: Pelecaniformes) del Terciario temprano de Antártida. Ameghiniana, 21:121-124.
WetMore, A. 1928. The systematic position of the fossil bird $C y$ phornis magnus. Canada, Department of Mines, Geological Survey, Bulletin, 49:1-4.

ACCEPTED 19 JUNE 1989

\title{
ANNOUNCEMENT
}

\section{TOULMIN COLLECTION OF \\ PALEOCENE AND EOCENE INVERTEBRATES}

\section{CHARLES W. COPELAND, JR., AND ANDREW K. RINDSBERG}

Geological Survey of Alabama, P.O. Box O, Tuscaloosa 35486

Lyman D. Toulmin, Jr. (1904-1984), was a tireless collector of Gulf Coast Tertiary mollusks and other invertebrates. In his later years, Toulmin was Professor of Geology at the Florida State University, retiring in 1975 to become an emeritus professor. His magnum opus on index fossils, Stratigraphic Distribution of Paleocene and Eocene Fossils in the Eastern Gulf Region, was published in 1977 as Geological Survey of Alabama Monograph 13 (2 vols., 602 p., 72 pls.). Although he named the Florida State University as the repository of his figured specimens (p. v), Toulmin transferred the collection, including additional unfigured specimens, to the Geological Survey of Alabama in 1979. The collection is available, with restrictions, for study by qualified researchers.

Related holdings at the Geological Survey include Coastal Plain fossils collected by E. R. Schowalter (T. A. Conrad topotypes), E. A. Smith, T. H. Aldrich, Otto Meyer, and Winnie McGlamery, especially from the Upper Cretaceous Selma Group (Mooreville Chalk, Demopolis Chalk, Ripley Formation, and Prairie Bluff Chalk) and the Eocene (Claibornian) Gosport Sand. A large portion of the early collections by Michael Tuomey was burned in 1865. The total holdings of the Geological Survey of Alabama are estimated at about 100,000 fossil specimens.

\section{ANNOUNCEMENT}

\section{FOURTH INTERNATIONAL CONGRESS OF \\ SYSTEMATIC AND EVOLUTIONARY BIOLOGY July $1-7,1990$}

A major scientific meeting of which the overall theme is "The Unity of Evolutionary Biology." The site of meeting will be the University of Maryland campus in College Park, Maryland (USA).

The meeting is cosponsored by the University of Maryland and the Smithsonian Institution. There will be a program of symposia, special lectures, and presented papers. Encompassing differing approaches to the study of the evolution of animals, plants, and microorganisms, the Congress symposia will focus on three major ideas:

1) Evolution in perspective: biodiversity, conservation, biotechnology, and global change.

2) Tempo and pattern of evolution: microevolutionary and macroevolutionary processes.

3) Systematics and phylogenetic reconstruction.

Keynote speakers scheduled to speak during the congress include Richard Leakey, Peter Raven, Edward O. Wilson, Stephen I. Gould, Douglas Futuyma, Geerat Vermeij, John Maynard Smith, Robert May, and Karel Leim, among others. For further information, please contact Congress Secretary ICSEB-IV, Department of Microbiology, University of Maryland, College Park, Maryland 20742 USA. 